\title{
Compounds of the methanolic leaf extract as chemotaxonomic markers for the Campanula pyramidalis complex (Campanulaceae)
}

\author{
Ivana B. Janković ${ }^{1}$, Milica M. DrobaC ${ }^{2}$, Dmitar V. LaKuŠićl ${ }^{*}$ \\ ${ }^{1}$ Institute of Botany and Botanical Garden, Faculty of Biology, University of Belgrade, \\ Takovska 43, 11000 Belgrade, Serbia \\ 2 Department of Pharmacognosy, Faculty of Pharmacy, University of Belgrade, Vojvode \\ Stepe 450, 11000 Belgrade, Serbia
}

\begin{abstract}
During the past few years, the isophylloid Campanula pyramidalis complex has been the subject of studies aimed at an improved understanding of the relationships within it. The center of distribution of the C. pyramidalis complex is in the Balkan Peninsula with some smaller parts of the area located in the south Apennines. Although 21 taxa of the $C$. pyramidalis complex were described, only four species are accepted: $C$. pyramidalis, C. versicolor, C. secundiflora and C. austroadriatica. In the present study, we propose compounds of the methanolic leaf extract as possible chemotaxonomic markers for the $C$. pyramidalis complex. Eleven flavonoids and two phenolic acids were detected in leaf extract using high-performance liquid chromatography with diode-array detection analysis. The investigated taxa of the $C$. pyramidalis complex differ in terms of the composition of the methanolic leaf extract. Clustering of investigated taxa is not completely consistent with the previously reported molecular and morphometric data.
\end{abstract}

Keywords: Campanula pyramidalis, chemotaxonomy, flavonoids, methanolic leaf extract, phenolic acids

\section{Introduction}

Many studies have been performed to elucidate some of the complicated relationships that exist within the Campanulaceae family. However, due to the large number of taxa it is hard to make a comprehensive study and a single classification system. Endemic or rare Campanula, as well as smaller groups, aggregates and complexes are at the focus of interests, since usually they are molecularly, morphologically, karyologically, and biogeographi-

* Corresponding author, e-mail: dlakusic@bio.bg.ac.rs 
cally distinctive (Kovanda and AnČEv 1989, Eddie and Ingrouille 1999, EdDIE et al. 2003, Shulkina et al. 2003, Cosner et al. 2004, Nikolov 2005, KovaČić and Nikolić 2006, Cupido et al. 2011, MANSiOn et al. 2012, StAmenKović et al. 2012).

Such a group is constituted by the Balkan »isophylloid« bellflowers (KovAČıć 2004, TKALEC et al. 2004) that belong to the Campanula pyramidalis complex also informally referred to as the »pyramidalis« aggregate (GESLOT 1984) or subsection Pyramidalis (KolAKOvsky 1992). The Balkan Peninsula is the center of the distribution of the C. pyramidalis complex with some small disjunct parts of the range that lay in the south Apennines (Fig 1.) (LAKUŠIĆ et al. 2013).

The Campanula pyramidalis complex is traditionally represented with three generally accepted species Campanula pyramidalis Linnaeus (1753: 164), Campanula versicolor Andrews (1804: 396) and Campanula secundiflora Visiani et Pančić (1862: 20) (Fedorov and KovAnda 1976, Greuter et al. 1984). According to the results of molecular phylogenetic study, the south Adriatic populations represent separate species, recently described as new - Campanula austroadriatica D. Lakušić et Kovačić (2013: 519) (LAKUŠIĆ et al. 2013).

Apart from the above mentioned species, there are 13 taxa at specific and at intraspecfic level and four hybrids described within the C. pyramidalis complex (LAKUŠIć et al. 2013). However, they are not geographically and taxonomically well-defined (LAKUŠić et al. 2013).

In this paper we rely on groups of populations that are presented with five clades (P. 1, P. 2, P. 3, S, V), well-supported on the phylogenetic networks and trees (LAKUŠIć et al. 2013):

P. 1 clade - C. pyramidalis s. str. - northern and central Adriatic coast (Fig. 1),

P. 2 clade - C. austroadriatica sp. nova - southern Adriatic coast from the Neretva River canyon to northern Albania (Fig. 1),

P. 3 clade - C. »montenegrina « prov. - populations from the continental part of Montenegro traditionally considered as part of $C$. pyramidalis s. lato (Fig. 1). Molecularly this clade is much closer to $C$. secundiflora. Therefore, we apply the concept of R. Lakušić, who

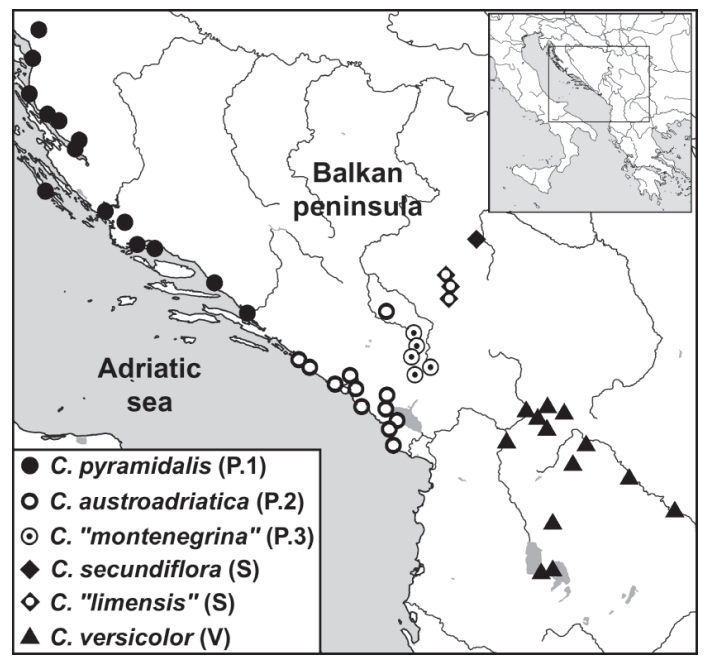

Fig. 1. Distribution of the Campanula pyramidalis complex in the investigated area. Symbols P.1-3, S and V correspond to molecular clades (LAKUšIĆ et al. 2013). 
originally recognized these groups of populations as C. secundiflora subsp. montenegrina $\mathrm{R}$. Lakušić (LAKUŠić et al. 2013),

S clade - C. secundiflora $\mathrm{s}$. lato - which includes $C$. secundiflora subsp. secundiflora from the gorge of the Panjica River in south-west Serbia, and C. secundiflora subsp. limensis R. Lakušić (LAKUŠić et al. 2013) from the canyons of the Lim and the Mileševka in south-west Serbia and northern Montenegro (Fig. 1), and

V clade $-C$. versicolor - southern parts of the Balkan Peninsula (Macedonia, Albania, Greece, Bulgaria) (Fig. 1).

Previous phytochemical studies on the plants of the genus Campanula revealed the presence of different secondary metabolites such as flavonoids, phenolic acids, anthocyanins and triterpenoids (CuEndet et al. 2001, YAYLI et al. 2003, YAYLI et al. 2005, TouAfeK et al. 2011). The presence of volatile oils in some Campanula species was described as well (ToSUN et al. 2011, KADRIYE et al. 2012, Politeo et al. 2013). Isoenzyme variability among nine Campanula taxa from Croatia and Bosnia and Herzegovina, including Campanula pyramidalis, has been studied (TKALEC et al. 2004).

The main goal of our present phytochemical analysis is to investigate the possibility of the use compounds of the methanolic leaf extract as possible chemotaxonomic markers for the $C$. pyramidalis complex. Furthermore, our goal is to determine if phytochemical data provide any correspondence with and support for the establishment of currently recognized or previously described taxa within this complex, especially for the unrecognized taxa $C$. »montenegrina« and C. »limensis«.

\section{Materials and methods}

\section{Plant material}

The aerial parts of Campanula species were collected from different locations in Croatia, Serbia, Montenegro and Macedonia (Tab. 1, Fig. 1). Voucher specimens of each sample have been deposited in the Herbarium of the Institute of Botany and Botanical Garden (BEOU), Faculty of Biology, University of Belgrade (Tab. 1).

In addition to the formal names $C$. pyramidalis, C. versicolor, C. secundiflora and $C$. austroadriatica that are registered in the International Plant Names Index (IPNI), in this paper we have used informal names $C$. »montenegrina« and $C$. »limensis«. These informal names are used in order to emphasize morphological (JANKOvić et al. 2013) and molecular specificities of the population from the canyon of the Morača River and the mountains in its surroundings ( $C$. »montenegrina $)$, as well as the populations from the canyons of the rivers Lim and Mileševka (C. »limensis«) (LAKUŠIĆ et al. 2013).

\section{Phytochemical analysis}

The air-dried and finely ground leaves were extracted twice with methanol $(1: 15 \mathrm{w} / \mathrm{v})$ using an ultrasonic bath for $30 \mathrm{~min}$, left to stand for $24 \mathrm{~h}$ and filtered. The extract was combined, concentrated in a rotary evaporator under reduced pressure for total solvent removal and dissolved in methanol prior to analysis in the concentration of $10 \mathrm{mg} \mathrm{mL}^{-1}$.

High-performance liquid chromatography (HPLC) analysis was performed on an Agilent 1100 Series system consisting of a G 1312A binary pump, a G1328B injector $(20 \mu \mathrm{L}$ 
Janković I. B., Drobac M. M., Lakušić D. V.

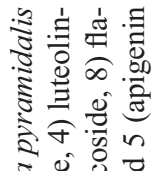

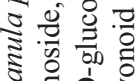

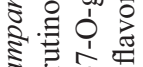

어의

依

范 寻 离.

告会

角官部

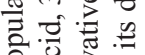

용.

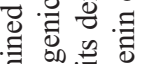

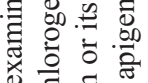

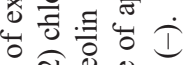

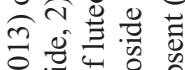

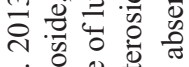

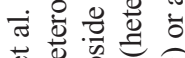

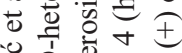

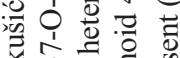

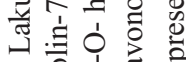

0 过灾

을 긍응

范

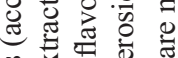

造 06

焉定

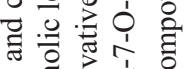

on 를

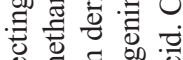

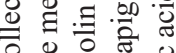

ठ월

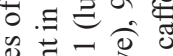

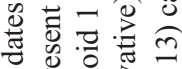

की

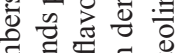

言話貝总

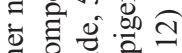

氖 है:

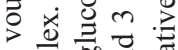

은

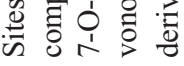

ส

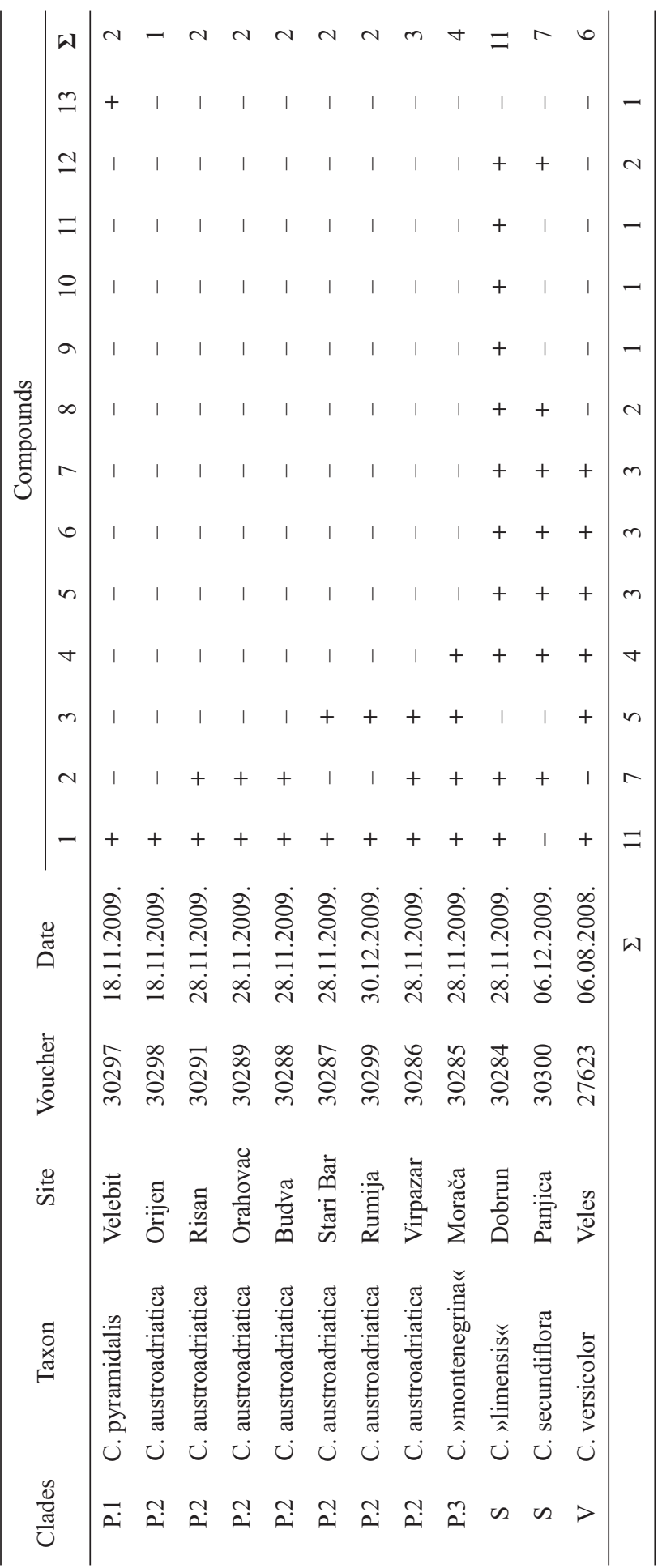


sample loop) and G1315B DAD detector, equipped with ZORBAX Eclipse XDB-C18 column $(4.6 \times 250 \mathrm{~mm}, 5 \mu \mathrm{m})$. A gradient elution was performed with solvent A $(0.03 \%(\mathrm{v} / \mathrm{v})$ $\mathrm{H}_{3} \mathrm{PO}_{4}, \mathrm{pH}=2.8$ ) and solvent $\mathrm{B}$ (solvent A:acetonitrile $=10: 90$ ) as follows: in $0 \mathrm{~min}, 15 \%$ $\mathrm{B}$; in $25 \mathrm{~min} 25 \% \mathrm{~B}$; in $30 \mathrm{~min} 35 \% \mathrm{~B}$; in $35 \mathrm{~min} 50 \% \mathrm{~B}$; in $40 \mathrm{~min} 70 \% \mathrm{~B}$ and in $45 \mathrm{~min}$ $15 \% \mathrm{~B}$. The column temperature was $25^{\circ} \mathrm{C}$, flow rate $1.0 \mathrm{~mL} \mathrm{~min}^{-1}$ and the injection volume was $30 \mu \mathrm{l}$. The spectra were acquired from 190 to $400 \mathrm{~nm}$. Detection was performed at 250, $320,340,350$ and $370 \mathrm{~nm}$. All analyses were carried out in triplicate.

Identification of compounds was carried out by comparing their spectra and their retention times with those of standards (luteolin, luteolin 7-O-glucoside, apigenin 7-O-glucoside, chlorogenic acid and caffeic acid) as well as with literature spectral data (MABRY et al. 1970, MARKHAM 1982).

\section{Statistical analysis}

FLORA software (KARADŽIĆ et al. 1998) was used for cluster analysis (Fig. 2) in order to determine the structure and separation of the populations based on presence / absence of compounds of methanolic leaf extract. Populations were classified using the optimal cluster method based on Jaccard's distance as a heterogeneity measure. The relation between populations and components of methanolic leaf extract originated by principal component analysis (PCA) was also obtained by using FLORA software and it is presented in form of bi-plot (Fig. 3).

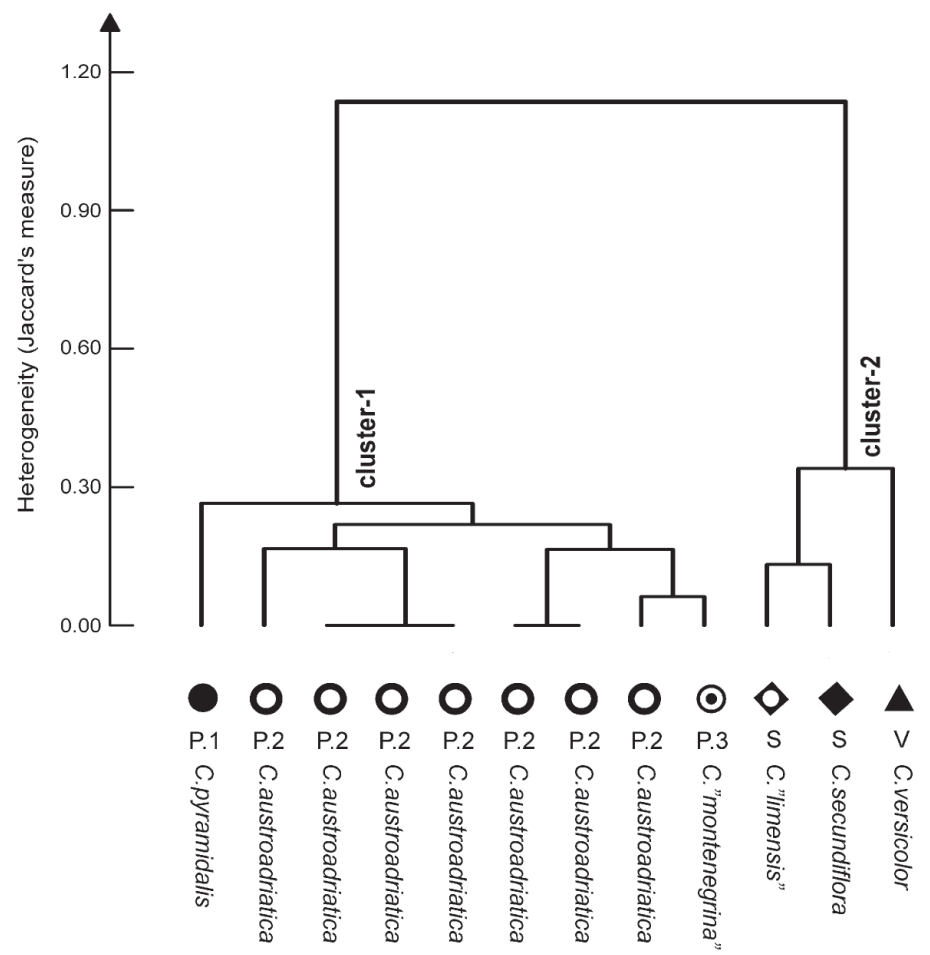

Fig. 2. Cluster analysis for whole data set. Symbols P.1-3, S and V correspond to molecular clades (LAKUŠIĆ et al. 2013). 


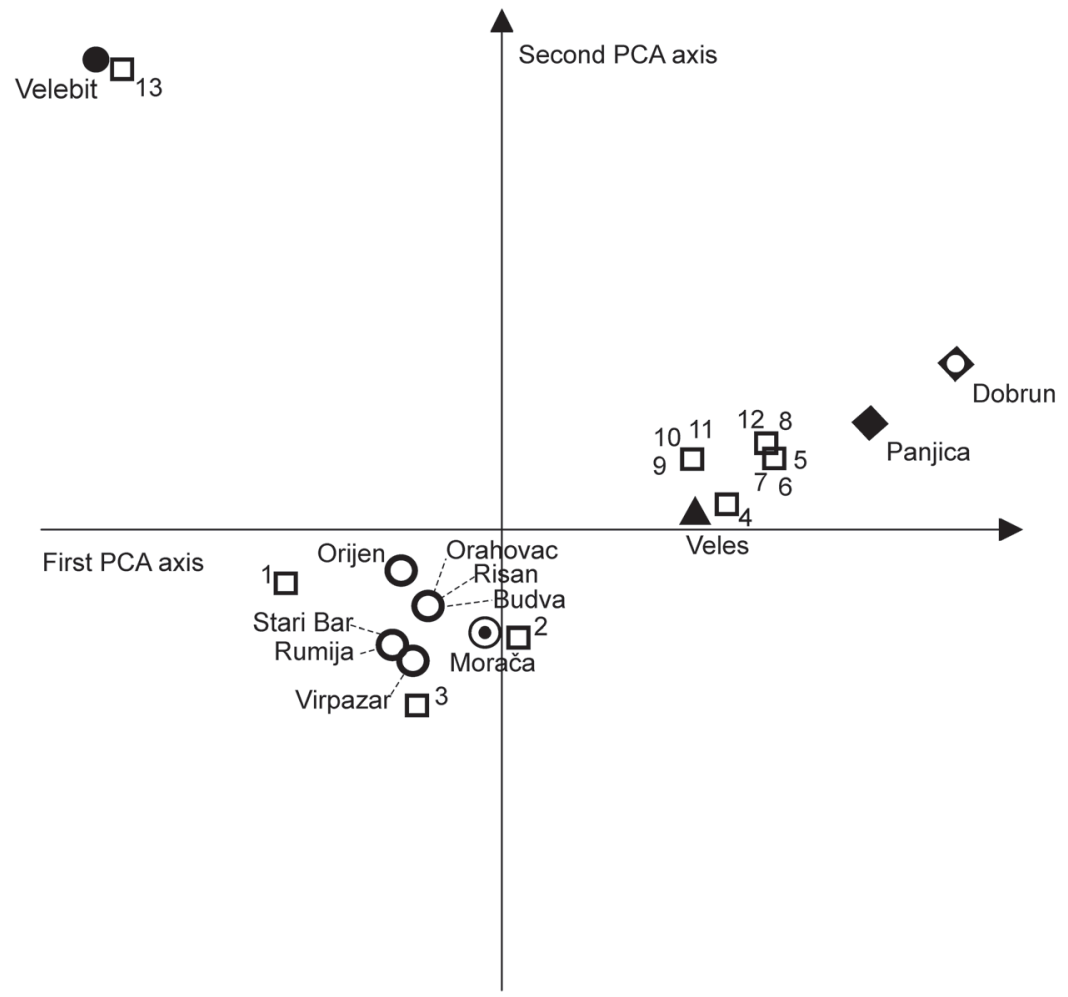

Fig. 3. Bi-plot principal component analysis (PCA) for populations and compounds detected in the methanolic leaf extract of the Campanula pyramidalis complex. Numbers from 1 to 13 , next to the white rectangles, correspond to number of compounds from table 1. Other symbols correspond to clades as explained in figure 1 .

\section{Results and discussion}

This study represents one of the first insights into the chemical compounds of the Campanula pyramidalis complex. A total of 11 flavonoids and 2 phenolic acids were detected in the methanolic leaf extract of 12 populations of 6 taxa (Tab. 1). The flavonoids present are flavones, either free aglycon (luteolin) or heterosides of apigenin, luteolin and its derivatives. Luteolin and its glycosides were also identified previously in the genus Campanula (Teslov 1990, Yayli et al. 2003, TouAfeK et al. 2011). Concerning the phenolic acids, chlorogenic acid was identified in the methanolic leaf extract of $C$. austroadriatica, $C$. "montenegrina«, $C$. »limensis« and $C$. secundiflora whereas caffeic acid was present only in $C$. pyramidalis. The mentioned acids were previously reported in some species of the genus Campanula (C. cephalotes, C. maleevii, C. rotundifolia, C. persicifolia) (Teslov and Blinova 1973, Teslov et al. 1983, Teslov and Podushrin 1988).

The result of the cluster analysis has shown that two main clusters stand out (Fig. 2): (i) cluster $1-C$. pyramidalis, C. austroadriatica and C. »montenegrina«; (ii) cluster $2 C$. secundiflora, $C$. »limensis « and $C$. versicolor. Luteolin 7-O-heteroside is present in almost all populations but absent only in $C$. secundiflora. Generally, we can conclude that popula- 
tions are characterized by the regular presence of luteolin 7-O-heteroside and the occasional presence of chlorogenic acid and/or luteolin 7-O-rutinoside (Tab. 1). Therefore, we can conclude that luteolin 7-O-heteroside, chlorogenic acid and luteolin 7-O-rutinoside are less responsible for separation of taxa than other compounds (Fig. 3). A luteolin derivative (labeled as flavonoid 1 in Tab. 1), 7-O-heteroside of luteolin or its derivative (flavonoid 2 in Tab. 1) and apigenin 7-O-glucoside are the compounds that separate cluster 1 from cluster 2. Campanula pyramidalis s.s. is unique in producing caffeic acid besides luteolin 7-Oheteroside. Caffeic acid is a common phenolic constituent of Campanulaceae (LAMmERS 2007). Luteolin 7-O-glucoside is present in taxa that belong to cluster 2 . However, luteolin 7-O-glucoside has also been detected in $C$. »montenegrina « from cluster 1 . The presence of luteolin 7-O-glucoside is another evidence that $C$. "montenegrina is associated with $C$. secundiflora and C. versicolor as molecular data has showed. Campanula secundiflora and C. »limensis « differ from other taxa by the presence of two flavonoids, luteolin and an apigenin derivative (flavonoid 3 in Tab. 1). Campanula »limensis « is distinguished by the presence of three compounds: apigenin 7-O-diheteroside, heteroside of apigenin or its derivative (flavonoid 4 in Tab. 1) and an apigenin derivative (flavonoid 5 in Tab. 1), which are not found in other taxa examined.

The chemical data indicate that within the $C$. pyramidalis complex the Mediterranean and sub-Mediterranean populations C. pyramidalis s. s. (P.1), C. austroadriatica (P.2) and C. »montenegrina« (P.3) form one group, while other group is represented by the continental populations of $C$. secundiflora $(\mathrm{S})$, C. »limensis « (S) and C. versicolor (V). However, the results of methanolic leaf extract analysis are inconsistent with molecular phylogenetic data. In fact, molecular data has showed that $C$. pyramidalis s. s. (P.1) is the most distant taxon at genetic level, forming one main cluster, while C. austroadriatica (P.2) forms a second main cluster. The third main cluster is represented by $C$. »montenegrina« (P.3) and C. secundiflora (S) (LAKUŠÍc et al. 2013).

Especially interesting is the position of $C$. »montenegrina « (P.3), due to its chemical characteristics nested within cluster 1 with $C$. pyramidalis s. str. (P.1) and C. austroadriatica (P.2). This relation of $C$. »montenegrina« (P.3) with other investigated taxa is inconsistent with respect not only to molecular but also to morphometric data, which suggest that $C$. »montenegrina (P.3) is part of C. secundiflora s. 1. (JANKOVIĆ and LAKUŠIĆ 2011, JANKOviĆ et al. 2013, LAKUŠIĆ et al. 2013). Campanula »montenegrina« occupies a transition zone between the Adriatic and the continental bellflowers belonging to the $C$. pyramidalis complex (JANKOvić et al. 2013). Also, it inhabits a wider range of altitudes from canyons to high mountains. The chemotaxonomic, molecular phylogenetic and morphometric results emphasize the necessity to investigate the populations that lie in the continental part of Montenegro more fully. Those populations are morphologically and geographically very specific and therefore they require a new taxonomic treatment (LAKUšić et al. 2013).

The second cluster, to which belong $C$. secundiflora s. s. (S), C. »limensis« (S) and $C$. versicolor $(\mathrm{V})$, is differentiated in the same way chemically and molecularly (LAKUŠIć et al. 2013). From all taxa investigated in this study, C. »limensis« is highly differentiated in the composition of the methanolic leaf extract by the number of different flavonoids. Eleven different compounds were detected in the methanolic leaf extract of $C$. »limensis«. It differs even from its closest taxon C. secundiflora s. s. Morphometric data (JANKOVIĆ and LAKUŠIĆ 2011, JANKOviĆ et al. 2013) also suggest that $C$. »limensis « is separate entity and its taxonomic status should be seriously reconsidered in future studies. 
Chemotaxonomic results based on the analysis of methanolic leaf extract demonstrated that investigated taxa of the $C$. pyramidalis complex are different. Therefore, our results suggest that the presence or absence of certain compounds in the methanolic leaf extract can be used as chemotaxonomic markers for further studies of the C. pyramidalis complex.

\section{Acknowledgements}

The authors gratefully acknowledge the financial support provided by the Serbian Ministry of Science and Technological Development (Project No. 173021 - Examination of potential medicinal plants: morphological, chemical and pharmacological characterization and 173030 - Biodiversity of the plant life of Serbia and Balkan Peninsula - Assessment, sustainable use and conservation). Also, we would like to offer our special thanks to Dijana Dobrota (Magdeburg, Germany) for improving the language of the manuscript.

\section{References}

Andrews, H. C., 1804-1805: The botanist's repository 6, 396.

Cosner, M. E., Raubeson, L. A., Jansen, R. K., 2004: Chloroplast DNA rearrangements in Campanulaceae: phylogenetic utility of highly rearranged genomes. BMC Evolutionary Biology 4, 27.

Cuendet, M., Potterat, O., Hostettmann, K., 2001: Flavonoids and phenylpropanoids derivatives from Campanula barbata. Phytochemistry 56, 631-636.

Cupido, C. N., Eddie, W. M. M., Tiedt, L. R., 2011: Systematic and ecological significance of seed coat morphology in South African Campanulaceae sensu stricto. Edinburgh Journal of Botany 68, 351-371.

Eddie, W. M. M., Ingrouille, M. J., 1999: Polymorphism in the Aegean »five-loculed« species of the genus Campanula, section Quinqueloculares (Campanulaceae). Nordic Journal of Botany 19, 153-169.

Eddie, W. M. M., Shulkina, T., Gaskin, J., Haberle, R. C., Jansen, R. K., 2003: Phylogeny of Campanulaceae s. str. inferred from ITS sequences of nuclear ribosomal DNK. Annals of the Missouri Botanical Garden 90, 334-375.

Fedorov, A. A., Kovanda, M., 1976: Campanula L. In: Tutin, T. G., Burges, N. A., Chater, A. O., Edmondson, J. R., Heywood, V. H., Moore, D. M., Valentine, D. H., Walters, S. M., WebB, D. A. (eds.), Flora Europaea 4, 4-93. Cambridge University Press, Cambridge, UK.

Geslot, A., 1984: Campanula L. In: Greuter, W., Burdet, H. M., Long, G. (eds) MedChecklist: A critical inventory of vascular plants of the circum-Mediterranean countries Vol. I. Ville de Geneve: Conservatoire et Jardin Botanique, Ville de Geneve.

Greuter, W., Burdet, H. M., Long, G., (1984): Med-Checklist, vol. 1 Conservatoire et Jardin Botanique, Ville de Geneve.

JANKOVIĆ, I., LAKUŠIĆ, D., 2011: Morphological differentiaion of isophylloid bluebells Campanula pyramidalis complex (Campanulaceae) in the Dinarides. Proceedings of International conference »Nature Protection in XXIst Century« 2, Žabljak, 913-914.

Janković, I., KuZmanović, N., LAKušić, D., 2013: An insight into the morphological variability of Balkan paleo-endemic Campanula secundiflora species complex (Campanu- 
laceae) inferred from traditional and geometric morphometics. Book of abstracts of 4th Croatian Botanical Symposium, Split, Croatia, 181.

Karadžić, B., ŠAšo-Jovanović, V., Jovanović, Z., Popović, R., 1998: FLORA- a database and software for floristic and vegetation analyzes. In: Tsekos, I., Moustakas, M. (eds.), Progress in botanical research, 69-72. Kluwer Academic Publishers, Dodrecht.

Kadriye, S., Nagihan Yilmaz, I., Nurettin, Y., 2012: Antimicrobial activity and chemical composition of the essential oil form Campanula glomerata L. subsp. hispida (Witasek) Hayek. Asian Journal of Chemistry 24, 1931.

Kolakovsky, A. A., 1992: Campanulaceae. In: Meusel, H., Jäger, E. J. (eds.), Vergleichende Chorologie der Zentraleuropaeischen Flora 3, 170-171. Gustav Fischer Verlag, Jena.

Kovačić, S., 2004: The genus Campanula L. (Campanulaceae) in Croatia, circum-Adriatic and west Balkan region. Acta Botanica Croatica 63, 171-202.

Kovačıć, S., Nikolić, T., 2006: Relations of the western Balkan endemic Campanula L. (Campanulaceae) lineages based on comparative floral morphometry. Plant Biosystems $140,260-272$.

Kovanda, M., AnČEv, M., 1989: The Campanula rotundifolia complex in Bulgaria. Preslia 61, 193-207.

Lakušić, D., Liber, Z., Nikolić, T., Surina, B., Kovačić, S., Bogdanović, S., Stefanović, S., 2013: Molecular phylogeny of the Campanula pyramidalis species complex (Campanulaceae) inferred from chloroplast and nuclear non-coding sequences and its taxonomic implications. Taxon 62, 505-524.

LAmmers, T. G., 2007: Campanulaceae. In: JoAchim, J., Jadereit, W. (eds), The families and genera of vascular plants 8: Flowering plants, Eudicots, Asterales, 26-56. Springer, Berlin.

Linnaeus, C., 1753: Species Plantarum, 164. Holmiae: Impensis Laurentii Salvii.

Mansion, G., Parolly, G., Crowl, A. A., Mavrodiev, E., Cellinese, N., Oganesian, M., Fraunhofer, K., Kamari, G., Phitos, D., Habarle, R., Akaydin, G., Ikinci, N., Taus, T., Borsch, T., 2012: How to handle speciose clades? Mass taxon-sampling as a strategy towards illuminating the natural history of Campanula (Campanuloideae). PLoS ONE $7,1-23$.

Mabry, T. J., Markham, K. R., Thomas, M. B., 1970: The systematic identification of flavonoids. Springer Verlag, New York.

Markham, K. R., 1982: Techniques of flavonoid identification. Academic Press, London.

Nikolov, Z., 2005: Taxonomy and chorology of genus Campanula L. (Campanulaceae) in Skopska kotlina (in Macedonian), MSc. Thesis, University Sv. Kiril and Metodij, Faculty of Science, Skopje.

Politeo, O., Skocibusic, M., Burcul, F., Maravic, A., Carev, I., Ruscic, M., Milos, M., 2013: Campanula portenschlagiana Roem. et Schult.: Chemical and antimicrobial activities. Chemistry \& Biodiversity 10, 1072-1080.

Stamenković, V., Jelenčić, B., Tkalec, M., 2012: Propagation and antioxidative enzymes of Campanula velebitica Borbas grown in vitro. Periodicum Biologorum 114, 77-82. 
Shulkina, T. V., Gaskin, J. F., Eddie, W. M. M., 2003: Morphological studies toward an improved classification of Campanulaceae s. str. Annals of Missouri Botanical Garden $90,576-591$.

TesLov, L. S., 1990: Flavonoid glycosides of Campanula persicifolia. Chemistry of Natural Compounds 26, 223.

Teslov, L. S., Blinova, K. F., 1973: Benzoic and cinnamic acids from Campanula cephalotes. Chemistry of Natural Compounds 9, 625.

Teslov, L. S., Koretskaya, L. N., Tsareva, G. I., 1983: Phenolic compounds of Campanula rotundifolia and C. persicifolia. Chemistry of Natural Compounds 19, 367.

Teslov, L. S., Podushkin, V. Yu., 1988: Flavonoids of Campanula maleevii. Chemistry of Natural Compounds 24, 255.

TKalec, M., KovaČIć, S., Nikolić, T., 2004: Isoenzyme variability among isophyllous, »isophylloid « and heterophylloid Campanula representatives in Croatia. Book of abstracts of 1st Croatian Botanical Symposium with International Participation, Zagreb, 121122.

Touafek, O., Kabouche, Z., Brouard, I., Bermejo, J. B., 2011: Flavonoids of Campanula alata and their antioxidant activity. Chemistry of Natural Compounds 46, 968-970.

Tosun, G., Kahriman, N., Çoskunçelebi, K., Genç, H., Karaoglu S. A., Yayli, N., 2011: Chemical composition and biological activity of the essential oil of Campanula olympica Boiss. Asian Journal of Chemistry 23, 2389-2391.

Visiani, R. de, PAnčić, J., 1862: Plantae serbicae rariores aut novae. A Prof. Roberto de Visiani et Prof. Josepho Pančić descriptae et iconibus illustratae. Decas, I. Memorie del Reale Istituto Veneto di Scienze 10, 20.

Yayli, N., Yildirim, N., DoĞAn, N., Usta, A., Altun, L., 2005: Triterpenes from Campanula lactiflora. Journal of Asian natural Product Research 7, 771-775.

Yayli, N., Yildirim, N., Usta, A., Zkurt, S., Akgün, V., 2003: Chemical constituents of Campanula lactiflora. Turkish Journal of Chemistry 27, 749-755. 